\title{
Excessive Weight Gain during Full Breast-Feeding
}

\author{
Maria Grunewald Christian Hellmuth Hans Demmelmair Berthold Koletzko \\ Division of Metabolic and Nutritional Medicine, Dr. von Hauner Children's Hospital, Ludwig Maximilian University of \\ Munich, Munich, Germany
}

\section{Key Words}

Breast milk - Breast-feeding · Human milk composition ·

Protein · Growth · Obesity

\begin{abstract}
Background: Breast-feeding is considered to offer optimal nutrition for healthy infant growth and development. Observational studies have linked breast-feeding to reduced obesity. Case Observation: We observed an infant who was born macrosomic $(4.56 \mathrm{~kg})$ and showed excessive weight gain markedly exceeding the 97 th percentile of weight during full breast-feeding. At the age of 4 months, the weight was greater than $11 \mathrm{~kg}$. Clinical evaluation did not reveal any underlying pathology. After the introduction of complementary feeding and hence reduction of the breast milk intake, the excessive weight gain was attenuated and the slope of the percentile curve paralleled upper percentiles. Since this pattern suggested full breast-feeding as the driver of excessive weight gain, we analyzed the human milk composition at the infant age of 1 year and compared the results with published data on composition at this stage of lactation. $\boldsymbol{R e}$ sults: The milk contents of lactose, fat, fatty acids, polar lipids, carnitine species, and insulin were similar to the reference data. The adiponectin content was increased. The most remarkable alteration was a high milk protein content (mean $1.25 \mathrm{~g} / \mathrm{dl}$, reference $0.8 \mathrm{~g} / \mathrm{dl}$ ). Conclusions: A very high protein supply in infancy has been previously shown to increase
\end{abstract}

plasma concentrations of the growth factors insulin and IGF-1, weight gain, and later obesity. We speculate that interindividual variations in human milk adiponectin and protein contents may contribute to modulation of the growth of fully breast-fed infants and in this case may have contributed to excessive weight gain during full breast-feeding. This hypothesis merits being tested in future cohort studies.

(c) 2014 S. Karger AG, Basel

\section{Background}

Breast-feeding is recommended as the optimal source of nutrition for infants to support normal growth and development as well as long-term health [1]. Breast milk compositions vary with maternal diet, lifestyle, genetic determinants, and the duration of lactation [1-5]. However, little is known whether interindividual differences in human milk composition may induce relevant effects on infant growth and health outcomes. There are indications that variations in milk polyunsaturated fatty acid content induced by diet and genetic variations modulate cognitive development $[6,7]$ and the risk of asthma [8].

The presented data is part of a PhD thesis written by Maria Grunewald at the Medical Faculty of the Ludwig Maximilian University of Munich.

\section{KARGER}

E-Mail karger@karger.com

www.karger.com/anm
(C) 2014 S. Karger AG, Basel

0250-6807/14/0644-0271\$39.50/0
Berthold Koletzko, MD

Dr. von Hauner Children's Hospital, Ludwig Maximilian University of Munich Lindwurmstrasse 4

DE-80337 Munich (Germany)

E-Mail office.koletzko@med.uni-muenchen.de 


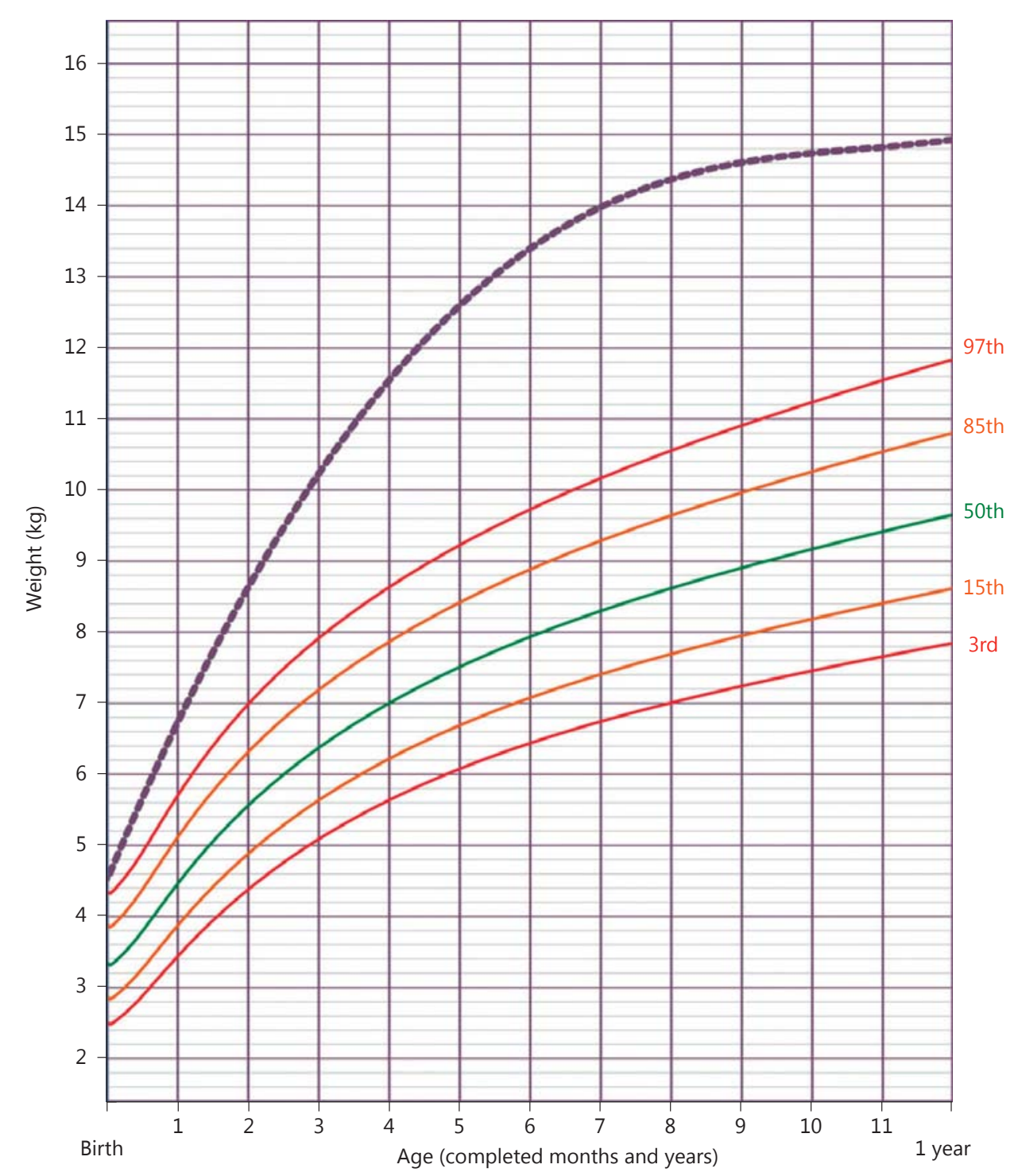

Fig. 1. Excessive gain of weight for age (dashed line) in the observed infant during the first 4 months of life during full breast-feeding, and attenuated weight gain during partial breast-feeding after the introduction of complementary feeding at the 5th month of life, plotted on the WHO weight-for-age reference [26].

Compared to formula feeding, breast-feeding is associated with a reduced risk of later obesity [9-11]. Traditionally, infant formulas have provided far higher protein contents than breast milk. A high protein supply in infancy in excess of the metabolic needs was proposed to induce increased plasma and tissue concentrations of insulin-releasing amino acids, increased secretion of the growth factors insulin and IGF-1, and thereby enhanced early weight gain and increased later obesity $[11,12]$. This hypothesis was confirmed in a large randomized clinical trial demonstrating that a high protein supply to infants increases their plasma amino acid and growth factor concentrations [13], early weight gain [14], and obesity rates at school age [15].

We observed a fully breast-fed infant with an extremely high weight gain and therefore analyzed the maternal milk composition to explore potential factors that may have influenced the highly unusual weight development. 
Table 1. Composition of fore- and hindmilk of the subject's mother at 1 year of lactation

\begin{tabular}{llc}
\hline Breast milk component & Foremilk & Hindmilk \\
\hline Macronutrients & & \\
Fat, g/dl & 1.4 & 4.05 \\
Carbohydrates, g/dl & 6.7 & 6.1 \\
Crude protein, g/dl & 1.1 & 1.4 \\
True protein, g/dl & 0.9 & 1.1 \\
Total solids, g/dl & 9.45 & 12.05 \\
Energy, kcal/dl & 44 & 68.5 \\
Adiponectin, ng/ml & 33.06 & 36.99 \\
Insulin, mU/l & 15.1 & 18.2 \\
Total carnitine, $\mu \mathrm{mol} / 1$ & 55.77 & 37.31 \\
Free carnitine, $\mu \mathrm{mol} / \mathrm{l}$ & 39.63 & 22.44 \\
Phosphatidylcholines, $\mu \mathrm{mol} / \mathrm{l}$ & 55.01 & 111.93 \\
Sphingomyelins, $\mu \mathrm{mol} / \mathrm{l}$ & 54.67 & 124.48 \\
\hline
\end{tabular}

\section{Case Report}

The male infant was born at $41^{+0}$ weeks of gestation as the second child of a 38-year-old, healthy mother after an uneventful pregnancy. The mother had a normal body weight and no gestational diabetes. The boy's older sister had been born with a weight of 3,200 g (-0.4 SD scores; SDS) but had become overweight during her breast-feeding period, whereas her weight had normalized again after cessation of breast-feeding. At the age of 5 years, her length was $106 \mathrm{~cm}(-0.41 \mathrm{SDS})$ and her weight was $17 \mathrm{~kg}(-0.43$ SDS). The boy was born by cesarean section with a birth weight of $4.56 \mathrm{~kg}(+2.14$ SDS $)$ and a length of $54 \mathrm{~cm}(+1.53$ SDS $)$. The infant was fully breast-fed for 4 months. His length increased along the 97th percentile for age, whereas his body weight rapidly increased to $11.5 \mathrm{~kg}$ at 4 months (+4.28 SDS). After the introduction of complementary feeding, the slope of weight gain was reduced and thereafter paralleled the 97 th percentile (fig. 1). At the age of 1 year, the child was referred to our department for further evaluation, with a weight of $15 \mathrm{~kg}(+3.12 \mathrm{SDS})$. There was a regular distribution of the excessive body fat, with circular fat folds, normal body proportions, and no signs of dysmorphism. No abnormalities of motor or neurological development were noted. Clinical and laboratory evaluations did not give any indication of an underlying genetic, syndromic, endocrine, or other abnormality. Rather, the course of the growth curve suggested an excessive weight gain velocity during the period of full breast-feeding, with normalization of the weight gain velocity after the introduction of complementary feeding and hence a reduced contribution of breast milk to the total dietary intake.

\section{Analysis of Breast Milk Composition}

The mother manually expressed samples of fore- and hindmilk at the boys' age of 1 year. We determined the macronutrient content in the fresh samples via mid-infrared transmission spectroscopy using a Miris Human Milk Analyzer (MIRIS AB, Uppsala, Sweden). The device is calibrated against ISO reference methods and provides the content of fat, carbohydrates, true protein and crude protein (including the nonprotein fraction), energy, and total solids.

Excessive Weight Gain during Full Breast-Feeding
Table 2. Fatty acid composition in human fore- and hindmilk of the subject's mother at 1 year of lactation, and reference data [18]

\begin{tabular}{|c|c|c|c|}
\hline $\begin{array}{l}\text { Fatty acid } \\
\text { composition, \% }\end{array}$ & Foremilk & Hindmilk & $\begin{array}{l}\text { Reference values } \\
\text { (mean } \pm \text { SEM) }\end{array}$ \\
\hline C10:0 & 1.39 & 1.39 & $1.14 \pm 0.026$ \\
\hline C12:0 & 7.87 & 7.91 & $6.53 \pm 0.169$ \\
\hline C14:0 & 8.82 & 9.11 & $9.27 \pm 0.220$ \\
\hline C14:1 & 0.17 & 0.17 & $0.40 \pm 0.016$ \\
\hline C15:0 & 0.27 & 0.28 & $0.45 \pm 0.016$ \\
\hline C16:0 & 21.76 & 21.79 & $24.15 \pm 0.222$ \\
\hline C17:0 & 0.29 & 0.29 & $0.40 \pm 0.008$ \\
\hline C18:0 & 7.43 & 7.58 & $8.43 \pm 0.267$ \\
\hline C20:0 & 0.20 & 0.22 & $0.66 \pm 0.014$ \\
\hline C22:0 & 0.07 & 0.08 & $0.07 \pm 0.003$ \\
\hline C24:0 & 0.05 & 0.06 & $0.05 \pm 0.002$ \\
\hline C16:1n-7 & 1.50 & 1.44 & $2.32 \pm 0.073$ \\
\hline C18:1n-9 & 31.93 & 31.61 & $30.21 \pm 0.261$ \\
\hline C18:1n-7 & 1.48 & 1.46 & $1.45 \pm 0.043$ \\
\hline C20:1n-9 & 0.37 & 0.37 & $0.22 \pm 0.005$ \\
\hline $\mathrm{C} 18: 2 \mathrm{tt}$ & 0.07 & 0.07 & $0.33 \pm 0.018$ \\
\hline C18:2n-6 & 13.17 & 13.13 & $9.28 \pm 0.345$ \\
\hline C18:3n-6 & 0.15 & 0.15 & $0.13 \pm 0.01$ \\
\hline $\mathrm{C} 18: 3 n-3$ & 0.96 & 0.91 & $0.79 \pm 0.031$ \\
\hline$C 20: 2 n-6$ & 0.23 & 0.20 & $0.06 \pm 0.001$ \\
\hline$C 20: 3 n-6$ & 0.25 & 0.24 & $0.19 \pm 0.006$ \\
\hline C20:4n-6 & 0.45 & 0.43 & $0.34 \pm 0.006$ \\
\hline$C 20: 5 n-3$ & 0.05 & 0.04 & $0.06 \pm 0.003$ \\
\hline$C 22: 4 n-6$ & 0.09 & 0.08 & $0.07 \pm 0.003$ \\
\hline$C 22: 5 n-3$ & 0.13 & 0.12 & $0.17 \pm 0.004$ \\
\hline$C 22: 6 n-3$ & 0.21 & 0.20 & $0.18 \pm 0.005$ \\
\hline
\end{tabular}

Aliquots of fore- and hindmilk were frozen at $-80^{\circ} \mathrm{C}$ and later thawed for analysis of the total lipid fatty acid composition by gas liquid chromatography [5] and total phosphatidylcholine and sphingomyelin and carnitine species via LC-MS/MS [16]. Milk adiponectin and insulin were measured by enzyme-linked immunosorbent assays (Human Adiponectin Elisa; BioVendor, Brno, Czech Republic, and Insulin Elisa; Mercodia, Uppsala, Sweden).

\section{Results and Discussion}

The results of the analysis of the mother's breast milk at 1 year postpartum are shown in tables 1 and 2 . The breast milk composition changes with the duration of lactation. At 1 year after birth, there are lower milk contents of protein, calcium, and saturated very-long-chain fatty acids, whereas the contents of lactose and total fat 
show little change compared to mature milk in the first months after birth [17]. Our results for milk contents of lactose, fat, and energy were within reported reference ranges $[6,17]$. The observed increase in total fat content from foremilk $(1.4 \mathrm{~g} / \mathrm{dl})$ to hindmilk $(4.1 \mathrm{~g} / \mathrm{dl})$ was expected [6]. The milk fatty acid composition (table 2) did not show appreciable differences from reported reference data [18]. The milk phosphoglyceride and sphingomyelin contents (table 1) were within the expected range of concentrations. Milk carnitine was higher in foremilk $(56 \mu \mathrm{mol} / \mathrm{l})$ than in hindmilk $(37 \mu \mathrm{mol} / \mathrm{l})$, with a calculated mean carnitine concentration in the dimension of values reported at 4 months of lactation (62 $\mu \mathrm{mol} / \mathrm{l})$ [19].

The mean milk insulin concentration of $16.7 \mathrm{mU} / \mathrm{l}$ was similar to reported milk insulin levels of about $15.64 \pm$ $1.03 \mathrm{mU} / \mathrm{l}$ [20]. The mean adiponectin concentration of $35.0 \mathrm{ng} / \mathrm{ml}$ was slightly higher than previously reported milk concentrations at 1 year of lactation of $25.7 \pm 1.4 \mathrm{ng} /$ $\mathrm{ml}$ [21]. Adiponectin receptor 1 was detected in rodent small intestine, which might facilitate the absorption of milk adiponectin and thus have the appetite-enhancing effect of high milk adiponectin levels [22]. In fact, high levels of breast milk adiponectin have been associated with an increased risk of child overweight at 2 years of age [23].

The high mean protein content of $1.25 \mathrm{~g} / \mathrm{dl}$ and the high protein concentration of $1.4 \mathrm{~g} / \mathrm{dl}$ in hindmilk are remarkable. The milk protein content was higher in colostrum and early mature milk and decreased significantly with increasing duration of lactation [6]. The milk of mothers of infants born at term usually has a protein concentration of $1.4 \mathrm{~g} / \mathrm{dl}$ at 1 month after birth and 0.8 $\mathrm{g} / \mathrm{dl}$ at 1 year postpartum [17]. Thus, the measured protein content in the milk of our subject's mother was 1.56fold (foremilk) to 1.75-fold (hindmilk) higher than expected.
While breast-feeding generally reduces the risk of a high weight gain and the development of obesity [9-11], in the infant reported here full breast-feeding induced excessive weight gain and marked obesity which was attenuated when the breast milk intake was reduced after the introduction of complementary feeding. While different factors such as feeding habits and the milk volume provided may have contributed to this highly unusual growth pattern, we consider it possible that an abnormal milk composition may have contributed to the child's obesity. Specifically, we observed a higher-than-usual milk adiponectin content, which was previously associated with increased later obesity in an observational study [23], and a high breast milk protein content concentration, which in the case of a high formula protein content has been shown to induce a high early weight gain as well as increased later obesity $[14,15]$. While the observation of a single case cannot prove causality, this observation leads us to hypothesize that interindividual variations in human milk composition may modulate child growth patterns and the obesity risk. We intend to investigate this hypothesis further by analyzing the human milk composition in mother-infant pairs followed in the EarlyNutrition research project $[24,25]$.

\section{Acknowledgement}

The work reported herein was carried out with partial financial support from the Commission of the European Communities, the 7th Framework Programme, contract FP7-289346-EARLY NUTRITION, and European Research Council Advanced Grant ERC-2012-AdG - No. 322605 META-GROWTH. This paper does not necessarily reflect the views of the Commission and in no way anticipates the future policy in this area.

\section{Disclosure Statement}

The authors declare no conflicts of interest.

\section{References}

ESPGHAN Committee on Nutrition, Agostoni C, Braegger C, Decsi T, Kolacek S, Koletzko B, Michaelsen KF, Mihatsch W, Moreno LA, Puntis J, Shamir R, Szajewska H, Turck D, van Goudoever J: Breast-feeding: a commentary by the ESPGHAN Committee on Nutrition. J Pediatr Gastroenterol Nutr 2009; 49:112-125.
Lattka E, Rzehak P, Szabo E, Jakobik V, Weck M, Weyermann M, Grallert H, Rothenbacher D, Heinrich J, Brenner H, Decsi T, Illig T, Koletzko B: Genetic variants in the fads gene cluster are associated with arachidonic acid concentrations of human breast milk at 1.5 and 6 mo postpartum and influence the course of milk dodecanoic, tetracosenoic, and trans-9-octadecenoic acid concentrations over the duration of lactation. Am J Clin Nutr 2011;93:382-391.
Koletzko B, Agostoni C, Bergmann R, Ritzenthaler K, Shamir R: Physiological aspects of human milk lipids and implications for infant feeding: a workshop report. Acta Paediatr 2011;100:1405-1415.

-4 Kunz C, Rodriguez-Palmero M, Koletzko B, Jensen R: Nutritional and biochemical properties of human milk. 1. General aspects, proteins, and carbohydrates. Clin Perinatol 1999; 26:307-333. 
5 Del Prado M, Villalpando S, Elizondo A, Rodriguez M, Demmelmair H, Koletzko B: Contribution of dietary and newly formed arachidonic acid to human milk lipids in women eating a low-fat diet. Am J Clin Nutr 2001;74: 242-247.

6 Jensen RG: Handbook of Milk Composition. San Diego, Academic Press, 1995.

-7 Jensen CL, Voigt RG, Llorente AM, Peters SU, Prager TC, Zou YL, Rozelle JC, Turcich MR, Fraley JK, Anderson RE, Heird WC: Effects of early maternal docosahexaenoic acid intake on neuropsychological status and visual acuity at five years of age of breast-fed term infants. J Pediatr 2010;157:900-905.

8 Standl M, Sausenthaler S, Lattka E, Koletzko $\mathrm{S}$, Bauer CP, Wichmann HE, von Berg A, Berdel D, Kramer U, Schaaf B, Lehmann I, Herbarth O, Klopp N, Koletzko B, Heinrich J: Fads gene cluster modulates the effect of breastfeeding on asthma: results from the GINIplus and LISAplus studies. Allergy 2012; 67:83-90.

-9 Arenz S, Ruckerl R, Koletzko B, von Kries R: Breast-feeding and childhood obesity - a systematic review. Int J Obes Relat Metab Disord 2004;28:1247-1256.

10 von Kries R, Koletzko B, Sauerwald T, von Mutius E, Barnert D, Grunert V, von Voss $\mathrm{H}$ : Breast feeding and obesity: cross sectional study. BMJ 1999;319:147-150.

11 Koletzko B, von Kries R, Monasterolo RC Subias JE, Scaglioni S, Giovannini M, Beyer J, Demmelmair H, Anton B, Gruszfeld D, Dobrzanska A, Sengier A, Langhendries JP, Cachera MF, Grote V: Infant feeding and later obesity risk. Adv Exp Med Biol 2009;646: $15-29$.
12 Koletzko B, Broekaert I, Demmelmair H, Franke J, Hannibal I, Oberle D, Schiess S, Baumann BT, Verwied-Jorky S: Protein intake in the first year of life: a risk factor for later obesity? The E.U. Childhood Obesity Project. Adv Exp Med Biol 2005;569:69-79.

13 Socha P, Grote V, Gruszfeld D, Janas R, Demmelmair H, Closa-Monasterolo R, Subias JE, Scaglioni S, Verduci E, Dain E, Langhendries JP, Perrin E, Koletzko B: Milk protein intake, the metabolic-endocrine response, and growth in infancy: data from a randomized clinical trial. Am J Clin Nutr 2011;94:1776S1784 S.

14 Koletzko B, von Kries R, Closa R, Escribano J, Scaglioni S, Giovannini M, Beyer J, Demmelmair H, Gruszfeld D, Dobrzanska A, Sengier A, Langhendries JP, Rolland Cachera MF, Grote V: Lower protein in infant formula is associated with lower weight up to age 2 years: a randomized clinical trial. Am J Clin Nutr 2009;89:1836-1845.

15 Weber M, Grote V, Closa-Monasterolo R, Escribano J, Langhendries JP, Dain E, Giovannini M, Verduci E, Gruszfeld D, Socha P, Koletzko B; for-the-The-European-ChildhoodObesity-Trial-Study-Group: Lower protein content in infant formula reduces BMI and obesity risk at school age: follow-up of a randomized trial. Am J Clin Nutr 2014;99:10411051.

16 Reinehr T, Wolters B, Knop C, Lass N, Hellmuth C, Harder U, Peissner W, Wahl S, Grallert $\mathrm{H}$, Adamski J, Illig T, Prehn C, Yu Z, Wang-Sattler R, Koletzko B: Changes in the serum metabolite profile in obese children with weight loss. Eur J Nutr 2014, E-pub ahead of print.

-17 Shehadeh N, Aslih N, Shihab S, Werman MJ, Sheinman R, Shamir R: Human milk beyond one year post-partum: lower content of protein, calcium, and saturated very long-chain fatty acids. J Pediatr 2006;148:122-124.
8 Mitoulas LR, Gurrin LC, Doherty DA, Sherriff JL, Hartmann PE: Infant intake of fatty acids from human milk over the first year of lactation. Br J Nutr 2003;90:979-986.

19 Mitchell ME, Snyder EA: Dietary carnitine effects on carnitine concentrations in urine and milk in lactating women. Am J Clin Nutr 1991;54:814-820.

20 Whitmore TJ, Trengove NJ, Graham DF, Hartmann PE: Analysis of insulin in human breast milk in mothers with type 1 and type 2 diabetes mellitus. Int J Endocrinol 2012; 2012:296368.

21 Bronsky J, Mitrova K, Karpisek M, Mazoch J, Durilova M, Fisarkova B, Stechova K, Prusa R, Nevoral J: Adiponectin, AFABP, and leptin in human breast milk during 12 months of lactation. J Pediatr Gastroenterol Nutr 2011;52: 474-477.

22 Zhou Y, Sun X, Jin L, Stringfield T, Lin L, Chen Y: Expression profiles of adiponectin receptors in mouse embryos. Gene Expr Patterns 2005;5:711-715.

23 Weyermann M, Brenner H, Rothenbacher D: Adipokines in human milk and risk of overweight in early childhood: a prospective cohort study. Epidemiology 2007;18:722-729.

24 Brands B, Demmelmair H, Koletzko B; EarlyNutrition Project: How growth due to infant nutrition influences obesity and later disease risk. Acta Paediatr 2014;103:578-585.

25 Koletzko B, Brands B, Poston L, Godfrey K, Demmelmair H; EarlyNutrition Project: Early nutrition programming of long-term health. Proc Nutr Soc 2012;71:371-378.

26 World Health Organization: Child growth standards: weight-for-age - birth to 2 years. 2014. http://www.who.int/childgrowth/standards/chts_wfa_boys_p/en/ (accessed January 7,2014$)$. 